\title{
Serum high-molecular-weight adiponectin as a marker for the evaluation and care of subjects with metabolic syndrome and related disorders
}

\author{
Hiroshi Hirose ${ }^{1,2}$, Yukihiro Yamamoto², Yoshie Seino-Yoshihara², Hiroshi Kawabe ${ }^{1,2}$, and Ikuo Saito ${ }^{1,2}$ \\ ${ }^{1}$ Health Center, Keio University, Tokyo, Japan \\ ${ }^{2}$ Department of Internal Medicine, Keio University School of Medicine, Tokyo, Japan
}

In 1996, adiponectin was reported to be the most abundant transcript in adipose tissue. Animal studies revealed that administering adiponectin improves insulin resistance and blood glucose levels and inhibits atherosclerosis. In the present article, we review the significance of measuring serum high-molecular-weight (HMW) adiponectin levels in human subjects.

Our cross-sectional studies revealed that the serum HMW adiponectin concentration was 1.9 times higher in healthy Japanese females than males and had a strong positive correlation with HDLcholesterol but a negative correlation with BMI and the homeostasis model assessment insulin resistance index (HOMA-IR). They also indicated that the serum HMW adiponectin concentration had a stronger association with HOMA-IR and metabolic syndrome than the total adiponectin concentration.

Our longitudinal study, a 6-year follow-up of Japanese men, suggested that a decreased level of HMW adiponectin is a predictor of progression to metabolic syndrome. In another intervention study, lifestyle modification for 3 months induced a decrease in BMI and waist circumference and an increase in serum HMW adiponectin but not the total adiponectin level in 16 Japanese males with metabolic syndrome.

Administering thiazolidinediones to diabetic patients increased the serum HMW adiponectin concentration 3 fold and improved glucose and lipid profiles and blood pressure. Some people may inherit a lower serum concentration of adiponectin, and have a higher risk of developing cardiovascular diseases.

It is suggested that HMW adiponectin is a useful marker for the evaluation and care of subjects with metabolic syndrome and related disorders.

J Atheroscler Thromb, 2010; 17:1201-1211.

Key words; High-molecular-weight adiponectin, Metabolic syndrome, Insulin resistance, and Diabetes mellitus.

\section{Introduction}

The leading cause of death in Japan is cancer (malignant neoplasms 30.0\%), followed by heart dis-

Address for correspondence: Hiroshi HIROSE, MD, PhD, Health Center, and Department of Internal Medicine, School of Medicine, Keio University, 35 Shinanomachi, Shinjuku-ku, Tokyo 160-8582, Japan

E-mail: hhirose@hc.cc.keio.ac.jp

Received: June 23, 2010

Accepted for publication: August 3, 2010 ease $(15.9 \%)$ and cerebrovascular disease (11.1\%). However, the rate of mortality for cardiovascular diseases (CVDs), which include heart and cerebrovascular diseases, is almost the same as that for cancer (Vital Statistics 2008 by Ministry of Health, Labour and Welfare, Japan). Insulin resistance is the decreased ability to respond to the effects of insulin, and is caused by heredity factors, environmental factors such as a high-fat diet and reduced physical activity, and "glucose toxicity" due to hyperglycemia, etc. Since the introduction of a westernized diet and reduced physi- 


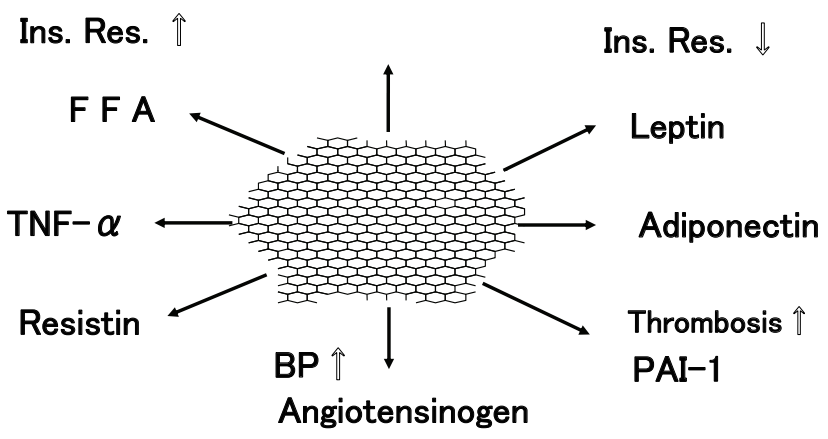

Fig. 1. Roles of adipo (cyto) kines secreted from adipose tissue.

Ins. Res.: Insulin resistance; FFA: free fatty acid; TNF: tissue necrosis factor; BP: blood pressure; PAI-1: plasminogen activator inhibitor-1.

cal activity in Japan, as reflected by automation and motorcars, the prevalence of lifestyle-related diseases such as abdominal obesity, type 2 diabetes mellitus, hypertension, dyslipidemia, and atherosclerotic diseases has increased and become a social problem. Because these conditions often develop concurrently via visceral fat accumulation and/or insulin resistance ${ }^{1)}$, they have been called syndrome $\mathrm{X}^{2)}$, the deadly quartet ${ }^{3)}$, insulin resistance syndrome ${ }^{4)}$, and visceral fat syndrome ${ }^{1)}$. Recently, this syndrome has been called metabolic syndrome. The above conditions pertaining to metabolic syndrome are important risk factors for atherosclerosis and CVDs, and comorbidity is known to increase the risk of CVDs, not additively, but synergistically ${ }^{5)}$. Therefore, to prevent and control metabolic syndrome and/or CVDs, it is important to help people recognize the importance of health checkups and correct visceral-type obesity and insulin resistance.

It has long been considered that adipose tissue only regulates energy storage, but recent studies have revealed that the tissue is a site of synthesis and secretion of various bioactive substances (called adipokines, Fig. 1) such as free fatty acids (FFAs), TNF- $\alpha$, resistin, leptin, adiponectin, PAI-1, and angiotensinogen ${ }^{1)}$. Fig. 2 shows the factors involved in the progression from obesity to atherosclerotic diseases, especially those involved in inducing insulin resistance and atherosclerosis.

In this article, we review the significance of measuring serum levels of high-molecular- weight (HMW) adiponectin for evaluating and caring for subjects with metabolic syndrome and related disorders.

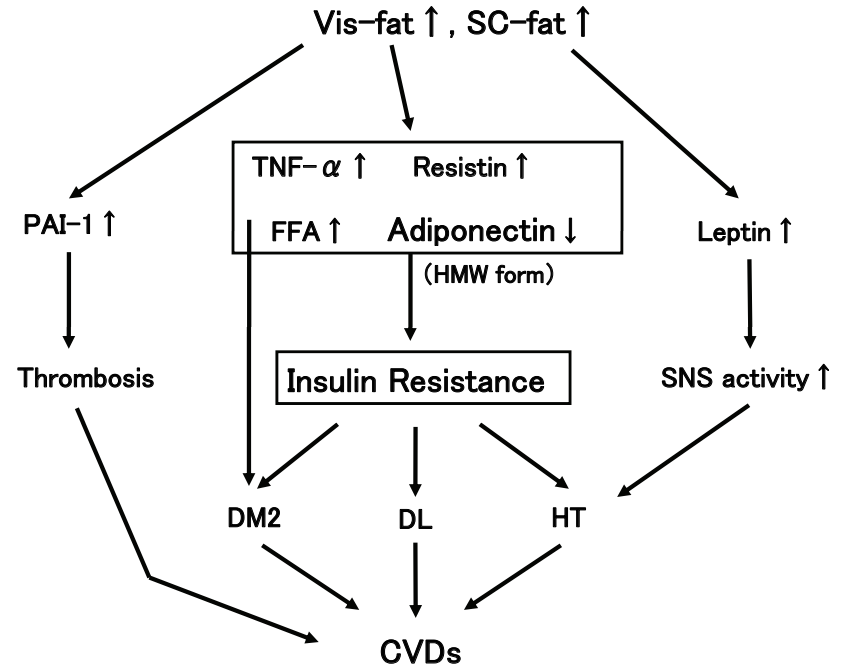

Fig. 2. Progression from obesity to cardiovascular disease (CVD).

Vis-fat: visceral fat; SC-fat: subcutaneous fat; HMW: high-molecular weight; SNS: sympathetic nervous system; DM2: type 2 diabetes mellitus; DL: dyslipidemia; HT: hypertension.

\section{What is Adiponectin?}

Adiponectin was discovered by researchers at Osaka University in 1996 as the most abundant transcript in adipose tissue ${ }^{6}$. It was found to be the same substance as a $28-\mathrm{kD}$ gelatin-binding protein (GBP28) extracted from human serum by the Faculty of Pharmaceutical Sciences, Showa University in the same year $^{7)}$.

Adiponectin inhibits signals triggering inflammation in vascular endothelial cells and the growth of vascular smooth muscle cells ${ }^{1)}$. In animal experiments, adiponectin reportedly attached to injured blood vessel walls. Yamauchi et al. ${ }^{8)}$ and Berg et al. ${ }^{9)}$ found separately in studies using various types of obese mice and diabetic mice, that the administration of adiponectin improves both insulin resistance and blood glucose levels. Another paper reported that the concentration of adiponectin in blood decreased in rhesus monkeys with diabetes as insulin resistance worsened ${ }^{10)}$. Furthermore, studies using knockout mice ${ }^{11,12)}$ indicated that a high-fat diet likely induces insulin resistance and atherosclerosis. Moreover, adiponectin was found to inhibit hepatic fibrosis ${ }^{13)}$ and the growth of cancer cells ${ }^{14)}$, and provide the survival benefits ${ }^{15)}$ in animal experiments.

Recent analyses by gel filtration have revealed that adiponectin is not present as a monomer in serum and that the HMW forms including the do- 
decamer $(4 \times 3$ mer $)$ and octadecamer $(6 \times 3$ mer $)$ are more closely associated with the onset of coronary artery diseases (CADs) and weight reduction ${ }^{16)}$ and play the role of insulin sensitizers ${ }^{17}$. Several studies in vitro have found that HMW adiponectin mainly activates AMP kinase ${ }^{18)}$, prevents apoptosis of vascular endothelial cells ${ }^{16)}$, and has cytostatic effects ${ }^{19)}$; thus, HMW adiponectin is an active form of adiponectin.

Clinical findings also confirmed that type 2 diabetic patients with CAD show a selective reduction in HMW adiponectin ${ }^{16,17,20)}$. Furthermore, weight reduction ${ }^{16)}$ increases the HMW form of adiponectin but not the lower molecular complexes. Waki et al. ${ }^{21)}$ revealed that human adiponectin with rare missense mutations (G84R and G90S) does not form HMW multimers. These mutations were associated with insulin resistance and type 2 diabetes mellitus. They concluded that the proportion of each adiponectin oligomeric complex is important for the anti-diabetic and anti-atherogenic activities of this protein.

Several reports have shown HMW adiponectin to be more useful than total adiponectin. In particular, in type 2 diabetic patients receiving medications that include thiazolidinediones (TZDs), the HMW/total adiponectin ratio was reported to be more useful than the total serum adiponectin level. For example, Pajvani et al. ${ }^{17)}$ reported that the HMW/total adiponectin ratio was significantly more useful for monitoring improvements in insulin sensitivity in response to TZDs in type 2 diabetes mellitus. Hara et al. ${ }^{22)}$ reported that the HMW/total adiponectin ratio had better power for predicting insulin resistance and metabolic syndrome than the total plasma adiponectin level. Aso et al. ${ }^{20)}$ reported that the HMW/total adiponectin ratio was more useful for evaluating CAD in type 2 diabetic patients than simply measuring the total serum adiponectin level. We conducted a cross-sectional study in healthy Japanese males without any medication and found that HMW adiponectin is as effective as the HMW/total adiponectin ratio for predicting insulin resistance and/or metabolic syndrome ${ }^{23)}$.

Recently, longitudinal data concerning HMW adiponectin have been reported. For example, a decreased HMW adiponectin level was found to be an independent risk factor for progression to type 2 diabetes in Japanese Americans during a 5.4-year followup study ${ }^{24)}$, and Inoue et al. reported that the serum HMW adiponectin level was a predictor of cardiovascular events in patients with CAD during a 7-year follow-up study ${ }^{25)}$.

\section{Cross-sectional study in healthy subjects}

Although adiponectin is secreted from adipocytes, adiponectin concentrations are reported to be lower in obese subjects ${ }^{26)}$ and in patients with type 2 diabetes mellitus and much lower in those with a combination of type 2 diabetes mellitus and $\mathrm{CAD}^{27)}$. Furthermore, a significant positive correlation was observed between plasma adiponectin concentrations and insulin sensitivity (effectiveness of insulin) in Pima Indians with severe obesity and diabetes ${ }^{28)}$.

In our cross-sectional study, 945 healthy Japanese males and females aged 30-65 years who participated in regular health check-ups were enrolled as study subjects, in order to examine the relationship between the serum HMW adiponectin concentration and body mass index (BMI), blood pressure, lipid profile, plasma glucose, serum insulin level, etc. The serum adiponectin concentration was determined using a commercially available kit (Chugai Diagnostics Science Co., Ltd, Tokyo) ${ }^{29-32)}$ with IH7, the same antibody used in a novel enzyme-linked immunosorbent assay (ELISA) kit specific for HMW adiponectin (Fujirebio Inc., Tokyo ${ }^{33)}$. IH7 specifically indentifies HMW adiponectin, rendering heat treatment unnecessary ${ }^{33)}$. Therefore, we are sure that the concentration measured was that of HMW adiponectin. In the present review article, the serum adiponectin concentration, which was determined using the former $\mathrm{kit}^{29-32)}$, was converted to the data obtained by the latter kit and described as the HMW adiponectin concentration.

The serum HMW adiponectin concentration was 1.9 times higher in female subjects than in male subjects. The HMW adiponectin level negatively correlated with the homeostasis model assessment insulin resistance index (HOMA-IR) and positively correlated with HDL-cholesterol in both male and female subjects, even after adjusting for age and BMI (Tables 1 and 2). A significant negative correlation between the concentration and blood pressure was also observed, but the correlation was not significant after adjusting for age and BMI. A stepwise multiple regression analysis revealed that the serum HMW adiponectin concentration was independently associated with gender, HDL-cholesterol, HOMA-IR, and BMI (Table 3). The strongest correlation was between the concentration and HDL-cholesterol, in both male and female subjects, but details of the mechanisms remain unclear. The total adiponectin concentration was also measured using a commercially available kit (Otsuka Pharmaceutical Co., Ltd, Tokyo) in our cross-sectional study. The study results ${ }^{23)}$ showed that the HMW adiponectin concentration had a stronger association 
Table 1. Simple regressions with high-molecular-weight (HMW) and total adiponectin (ADPN) levels in 646 Japanese males aged $30-65$ years

\begin{tabular}{|c|c|c|c|c|c|c|}
\hline \multirow[t]{2}{*}{ Parameter } & \multicolumn{2}{|c|}{ Value $\pm S D$} & \multicolumn{2}{|c|}{ HMW ADPN } & \multicolumn{2}{|c|}{ Total ADPN } \\
\hline & & & $r$ & & $r$ & \\
\hline Age & $47.4 \pm 11.1$ & (years) & 0.030 & NS & 0.012 & NS \\
\hline BMI & $23.6 \pm 3.0$ & $\left(\mathrm{~kg} / \mathrm{m}^{2}\right)$ & -0.351 & $* *$ & -0.305 & $* *$ \\
\hline Systolic BP & $124 \pm 18$ & $(\mathrm{mmHg})$ & -0.184 & $* *$ & -0.152 & $* *$ \\
\hline Diastolic BP & $77 \pm 12$ & $(\mathrm{mmHg})$ & -0.187 & $* *$ & -0.152 & $* *$ \\
\hline Glucose & $96 \pm 16$ & $(\mathrm{mg} / \mathrm{dL})$ & -0.141 & $* *$ & -0.135 & $* *$ \\
\hline Glycated Albumin & $15.0 \pm 2.0$ & (\%) & 0.079 & $*$ & 0.098 & $*$ \\
\hline Insulin & $5.5 \pm 4.1$ & $(\mu \mathrm{U} / \mathrm{mL})$ & -0.373 & $* *$ & -0.318 & $* *$ \\
\hline HOMA-IR & $1.33 \pm 1.09$ & $(-)$ & -0.376 & $* *$ & -0.325 & $* *$ \\
\hline Triglycerides & $125 \pm 98$ & $(\mathrm{mg} / \mathrm{dL})$ & -0.344 & $* *$ & -0.330 & $* *$ \\
\hline HDL-cholesterol & $58 \pm 15$ & $(\mathrm{mg} / \mathrm{dL})$ & 0.351 & $* *$ & 0.303 & $* *$ \\
\hline LDL-cholesterol & $129 \pm 30$ & $(\mathrm{mg} / \mathrm{dL})$ & -0.218 & $* *$ & -0.206 & $* *$ \\
\hline Uric acid & $6.4 \pm 1.2$ & $(\mathrm{mg} / \mathrm{dL})$ & -0.208 & $* *$ & -0.186 & $* *$ \\
\hline
\end{tabular}

NS: not significant, ${ }^{*} p<0.01,{ }^{* *} p<0.001$. HMW: $3.2 \pm 2.1 \mu \mathrm{g} / \mathrm{mL}$ for males.

BP: blood pressure; HOMA-IR: homeostasis model assessment insulin resistance index.

Table 2. Simple regressions with high-molecular-weight (HMW) and total adiponectin (ADPN) level in 299 Japanese female subjects aged 30-65 years

\begin{tabular}{|c|c|c|c|c|c|c|}
\hline \multirow[t]{2}{*}{ Parameter } & \multicolumn{2}{|c|}{ Value \pm SD } & \multicolumn{2}{|c|}{ HMW ADPN } & \multicolumn{2}{|c|}{ Total ADPN } \\
\hline & & & $r$ & & $r$ & \\
\hline Age & $38.3 \pm 9.9$ & (years) & 0.069 & NS & 0.089 & NS \\
\hline BMI & $20.6 \pm 2.9$ & $\left(\mathrm{~kg} / \mathrm{m}^{2}\right)$ & -0.216 & $* *$ & -0.187 & $* *$ \\
\hline Systolic BP & $109 \pm 16$ & $(\mathrm{mmHg})$ & -0.069 & NS & -0.010 & NS \\
\hline Diastolic BP & $65 \pm 10$ & $(\mathrm{mmHg})$ & -0.023 & NS & -0.089 & NS \\
\hline Glucose & $87 \pm 12$ & $(\mathrm{mg} / \mathrm{dL})$ & -0.236 & $* *$ & -0.247 & $* *$ \\
\hline Glycated Albumin & $15.3 \pm 1.5$ & (\%) & 0.062 & NS & 0.118 & NS \\
\hline Insulin & $3.9 \pm 2.4$ & $(\mu \mathrm{U} / \mathrm{mL})$ & -0.256 & $* *$ & -0.221 & $* *$ \\
\hline HOMA-IR & $0.85 \pm 0.55$ & $(-)$ & -0.292 & $* *$ & -0.260 & $* *$ \\
\hline Triglycerides & $65 \pm 36$ & $(\mathrm{mg} / \mathrm{dL})$ & -0.246 & $* *$ & -0.206 & $* *$ \\
\hline HDL-cholesterol & $71 \pm 15$ & $(\mathrm{mg} / \mathrm{dL})$ & 0.378 & $* *$ & 0.352 & $* *$ \\
\hline LDL-cholesterol & $110 \pm 29$ & $(\mathrm{mg} / \mathrm{dL})$ & -0.111 & NS & -0.093 & NS \\
\hline Uric acid & $4.4 \pm 0.9$ & $(\mathrm{mg} / \mathrm{dL})$ & -0.120 & $*$ & -0.056 & NS \\
\hline
\end{tabular}

NS: not significant, ${ }^{*} p<0.01,{ }^{* *} p<0.001$. HMW: $6.0 \pm 3.5 \mu \mathrm{g} / \mathrm{mL}$ for females.

BP: blood pressure; HOMA-IR: homeostasis model assessment insulin resistance index.

Table 3. Stepwise multiple regression with high-molecular-weight (HMW) adiponectin as a dependent variable in 938 Japanese subjects

\begin{tabular}{lccc}
\hline Variable & $\begin{array}{c}\text { Standardized } \\
\text { regression } \\
\text { coefficient }\end{array}$ & $F$ & $p$ \\
\hline Sex & 0.257 & 75.8 & $<0.001$ \\
HDL-cholesterol & 0.241 & 62.0 & $<0.001$ \\
HOMA-IR & -0.188 & 33.5 & $<0.001$ \\
BMI & -0.124 & 12.8 & $<0.001$ \\
\hline
\end{tabular}

Age and mean blood pressure were also permitted to enter the regression mode. HOMA-IR: homeostasis model assessment insulin resistance index; BMI: body mass index. $R^{2}=(0.606)^{2}=0.367$ 

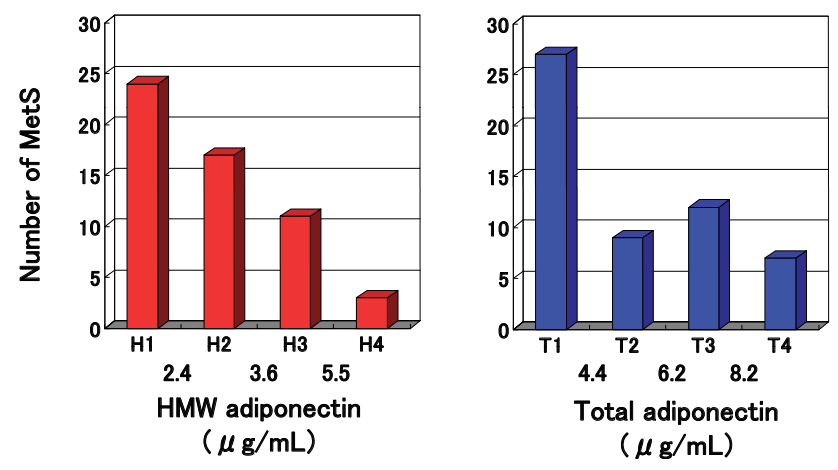

Fig. 3. Relationship of subject numbers with metabolic syndrome (MetS) and high-molecular- weight (HMW) (left panel) or total (right panel) adiponectin levels in 637 Japanese males divided into 4 groups according to each value.

with HOMA-IR and metabolic syndrome than the total adiponectin concentration (Fig. 3).

\section{Longitudinal studies related to the serum adiponectin level}

Although we could not identify the relationship between the HMW adiponectin concentration at baseline and changes in the BMI and lipid profile over 2 years, a significant negative correlation between the HMW adiponectin concentration at baseline and changes in insulin and HOMA-IR was observed ${ }^{31)}$. These associations were also significant after adjusting for changes in BMI. Thus, insulin resistance did not worsen much over 2 years when the serum HMW adiponectin concentration was high. In contrast, when the concentration was low, the insulin resistance worsened in 2 years.

A longitudinal study conducted by Daimon et al. in Funagata, Yamagata Prefecture, Japan, indicated hypoadiponectinemia to be a risk factor for the development of type 2 diabetes mellitus ${ }^{34)}$. Another study conducted in 18,225 American men aged 40-75 years found that nonfatal myocardial infarction or fatal coronary artery diseases developed in 226 subjects during the 6-year follow-up period and indicated a low blood concentration of adiponectin to be one of the predictors of myocardial infarction ${ }^{35)}$. Even after adjusting for age, study enrollment time, smoking, and other factors, the incidence of myocardial infarction in the lowest quartile of the adiponectin concentration was 2.5 times higher than that in the top quartile of the concentration $(p<0.001)^{35)}$.

We also investigated whether a decreased HMW adiponectin concentration is a predictor of progres- sion to metabolic syndrome during a 6-year follow-up period in Japanese men ${ }^{36)}$. This study included 416 men without metabolic syndrome, aged 30-59 years at baseline, who had participated in annual health checkups in both 2000 and 2006. The study found that a low concentration of HMW adiponectin $(\leq 2.65 \mu \mathrm{g} / \mathrm{mL})$ was associated with a substantially higher hazard ratio of the progression to metabolic syndrome after adjusting for age and BMI (hazard ratio 1.561, 95\% confidence interval 1.051-2.292, $p=0.028$ ). The number of subjects who progressed to metabolic syndrome in each tertile based on the baseline HMW adiponectin concentration was significantly different among the 3 groups (HMW adiponectin, $\chi^{2}=7.473, p=0.0238$; total adiponectin, $\chi^{2}=4.477, p=0.1066$; HMW/total ratio, $\chi^{2}=1.676, p=0.4325$ ).

In another intervention study, 16 Japanese males with metabolic syndrome aged $54.8 \pm 7.2$ years were enrolled in our program. Lifestyle modifications increasing physical activity and decreasing calories, were taught to each subject by physician nurses and by a nutritionist at our institute (Health Center, Keio University). Exercise training was performed by these subjects. Lifestyle modifications for 3 months induced decreases in BMI (though NS), waist circumference, and serum TG and post-prandial insulin levels (Table 4) and an increase in the serum HMW adiponectin level but not the total adiponectin level in these subjects (Table 5). We also found that the change in the HMW adiponectin level was most strongly correlated with the change in BMI $(r=-0.656, p=0.0046)$ but not significantly with the change in waist circumference $(r=-0.085, p=0.7586)$. Although the reason for this discrepancy was not clear, there is a possibility that the BMI reflected more precisely the reduction in body fat. In contrast waist circumference was not measured by one examiner in this study.

Furthermore, some papers have reported that the serum HMW adiponectin concentration increased slightly when angiotensin receptor blockers (ARBs), statins, and insulin secretagogues were administered. Losartan, an ARB, is widely used as an anti-hypertensive agent, and its metabolite is reported to have partial peroxisome proliferator-activated receptor gamma (PPAR $y$ ) activity in vitro ${ }^{37)}$. Several studies have demonstrated that losartan treatment increases the serum HMW-adiponectin level ${ }^{38,39)}$, although the effects of losartan on metabolic parameters in clinical use are controversial ${ }^{40-42)}$. On the other hand, treatment with diuretics, including hydrochlorothiazide (HCTZ) and indapamide, was reported to decrease the adiponectin level ${ }^{43-45)}$. We recently reported that changing the treatment to losartan/HCTZ from a usual dosage of 
Table 4. Beneficial effects of a 3-month lifestyle modification (mainly exercise) on metabolic parameters in 16 Japanese males with metabolic syndrome aged $54.8 \pm 7.2$ years

\begin{tabular}{lccc}
\hline & Baseline & 3 Months & $p$ value \\
\hline BMI $\left(\mathrm{kg} / \mathrm{m}^{2}\right)$ & $26.8 \pm 2.6$ & $26.6 \pm 2.5$ & $\mathrm{NS}$ \\
Waist circumference $(\mathrm{cm})$ & $91.9 \pm 6.4$ & $90.3 \pm 6.2$ & 0.0687 \\
Systolic blood pressure $(\mathrm{mmHg})$ & $135 \pm 19$ & $133 \pm 20$ & $\mathrm{NS}$ \\
Diastolic blood pressure $(\mathrm{mmHg})$ & $84 \pm 14$ & $85 \pm 13$ & $\mathrm{NS}$ \\
& & & \\
Fasting plasma glucose $(\mathrm{mg} / \mathrm{dL})$ & $119 \pm 23$ & $117 \pm 19$ & $\mathrm{NS}$ \\
Post prandial $(2 \mathrm{~h})$ glucose $(\mathrm{mg} / \mathrm{dL})$ & $146 \pm 52$ & $142 \pm 50$ & $\mathrm{NS}$ \\
Fasting serum insulin $(\mu \mathrm{U} / \mathrm{mL})$ & $10.7 \pm 4.2$ & $10.4 \pm 4.3$ & $\mathrm{NS}$ \\
Post-prandial $(2 \mathrm{~h})$ insulin $(\mu \mathrm{U} / \mathrm{mL})$ & $44.9 \pm 18.1$ & $35.8 \pm 17.1$ & 0.0032 \\
HOMA-IR & $3.1 \pm 1.3$ & $3.0 \pm 1.4$ & $\mathrm{NS}$ \\
Total cholesterol $(\mathrm{mg} / \mathrm{dL})$ & $214 \pm 46$ & $210 \pm 47$ & $\mathrm{NS}$ \\
Fasting serum TG $(\mathrm{mg} / \mathrm{dL})$ & $224 \pm 251$ & $153 \pm 95$ & $\mathrm{NS}$ \\
Post-prandial $(2 \mathrm{~h}) \mathrm{TG}(\mathrm{mg} / \mathrm{dL})$ & $269 \pm 255$ & $212 \pm 107$ & $\mathrm{NS}$ \\
HDL cholesterol $(\mathrm{mg} / \mathrm{dL})$ & $54 \pm 17$ & $53 \pm 14$ & $\mathrm{NS}$ \\
LDL-cholesterol $(\mathrm{mg} / \mathrm{dL})$ & $123 \pm 35$ & $132 \pm 40$ & $\mathrm{NS}$ \\
\hline
\end{tabular}

Values are means \pm SDs. By the Wilcoxon test.

HOMA-IR: homeostasis model assessment insulin resistance index; TG: triglycerides, NS: $p>0.15$.

Table 5. Beneficial effects of a 3-month lifestyle modification (mainly exercise) on serum adiponectin levels in 16 Japanese males with metabolic syndrome

\begin{tabular}{lccc}
\hline & Baseline & 3 Months & $p$ value \\
\hline Fasting & & & \\
HMW adiponectin & $2.5 \pm 1.8$ & $3.4 \pm 2.6$ & 0.0045 \\
Total adiponectin & $4.1 \pm 1.7$ & $4.3 \pm 2.1$ & $\mathrm{NS}$ \\
HMW/Total & $0.56 \pm 0.15$ & $0.71 \pm 0.24$ & 0.0016 \\
hr after meal test (541 kcal with 28.3g fat) & & & \\
HMW adiponectin & $2.6 \pm 2.1$ & $3.3 \pm 2.7$ & 0.0115 \\
Total adiponectin & $4.3 \pm 1.8$ & $4.2 \pm 2.1$ & $\mathrm{NS}$ \\
HMW/Total & $0.57 \pm 0.17$ & $0.71 \pm 0.24$ & 0.0023 \\
\hline
\end{tabular}

Values are means \pm SDs. By the Wilcoxon test.

HMW: high-molecular-weight, NS: $p>0.15$.

ARB, provided good blood pressure control, while the HMW-adiponectin level remained unchanged in male subjects with hypertension ${ }^{46)}$. We have found that administering telmisartan, which also has partial PPAR $y$ activity in vitro ${ }^{47-50)}$, increased the serum HMW adiponectin concentration in Japanese males with hypertension and abdominal obesity ${ }^{511}$.

\section{Studies in subjects with type 2 diabetes mellitus}

Our previous study ${ }^{52)}$ and others have shown that when troglitazone, an insulin sensitizer, was administered to type 2 diabetic patients for 3 to 6 months (400 mg/day), body weight and skinfold thickness increased but intra-abdominal fat decreased.
Since intra-abdominal fat is a well-known risk factor for insulin resistance and atherosclerosis ${ }^{1)}$, reducing intra-abdominal fat is important to prevent atherosclerosis.

We studied the effect of a 3-month administration of pioglitazone $(30 \mathrm{mg} /$ day $)$ in 10 Japanese males with type 2 diabetes mellitus $(57.7 \pm 7.4 \text { years })^{30)}$, using the same protocol as for troglitazone. The results indicated that the pioglitazone significantly decreased the subjects' fasting plasma glucose, insulin, blood pressure, and HbAic levels while significantly increasing BMI, LDL-cholesterol, and leptin levels. To our great surprise at that time, the mean serum HMW adiponectin concentration increased 3 fold in all cases $(3.2 \pm 1.1 \rightarrow 9.6 \pm 1.4 \mu \mathrm{g} / \mathrm{mL})$. A CT scan revealed that 
Table 6. Effects of a 3-month treatment with pioglitazone $(30 \mathrm{mg} /$ day $)$ on the high-molecular-weight (HMW) adiponectin level and liver function of 10 Japanese males with type 2 diabetes mellitus

\begin{tabular}{lccc}
\hline & Baseline & \multicolumn{2}{c}{3 months } \\
\hline Number & 10 & 10 & \\
HMW adiponectin $(\mu \mathrm{g} / \mathrm{mL})$ & $3.2 \pm 1.1$ & $9.6 \pm 1.4$ & $* *$ \\
$\quad$ AST $(\mathrm{IU} / \mathrm{L})$ & $27.9 \pm 13.2$ & $23.5 \pm 7.2$ & $\mathrm{NS}$ \\
ALT $(\mathrm{IU} / \mathrm{L})$ & $27.9 \pm 15.6$ & $22.9 \pm 9.4$ & NS \\
$\gamma$ GTP $(\mathrm{IU} / \mathrm{L})$ & $61.5 \pm 44.6$ & $47.9 \pm 40.1$ & $*$ \\
\hline
\end{tabular}

Data are means \pm SDs. ${ }^{*} p<0.05$ and ${ }^{* *} p<0.01$ by the Wilcoxon test.

NS: $p>0.10$.

the subcutaneous fat area $(S)$ significantly increased from $155 \pm 69$ to $179 \pm 81 \mathrm{~cm}^{2}$ and the visceral fat area (V) tended to increase (from $165 \pm 38$ to $180 \pm 46 \mathrm{~cm}^{2}$, and the V/S ratio from $1.2 \pm 0.3$ to $1.1 \pm 0.3$, NS for both), unlike with the troglitazone administration. Both troglitazone and pioglitazone activate $\operatorname{PPAR} \gamma$, a transcription factor present mainly in subcutaneous fat tissue; consequently, many reports indicate that body weight, subcutaneous fat, and leptin (mainly secreted from subcutaneous fat) increase with troglitazone and pioglitazone administration. However, the effects of troglitazone and pioglitazone on visceral fat were different. Although the precise mechanism is unknown, troglitazone contains vitamin $\mathrm{E}$ and so itself could have an effect on intra-abdominal fat. The above-mentioned study did not target patients with fatty liver, but an improvement in AST, ALT, and $\gamma$ GTP levels was also observed (Table 6). To summarize this study, the administration of pioglitazone to type $2 \mathrm{di}$ abetic patients improved their plasma glucose level and blood pressure and increased the serum HMW adiponectin concentration, suggesting pioglitazone to be useful for preventing the onset and progression of atherosclerosis in type 2 diabetic patients, as shown in the PROactive Study ${ }^{53)}$.

In keeping with the results of previous studies that reported an association between TZDs and the serum adiponectin concentration, the administration of troglitazone $e^{54)}$, pioglitazone ${ }^{30)}$, or rosiglitazone $e^{55)}$ increased the total adiponectin concentration approximately 2 fold and the serum HMW adiponectin concentration 3 fold. "Good adiponectin" and "bad TNF- $\alpha$ " are thought to inhibit each other's secretion and effects on muscles, suggesting that TZDs may inhibit TNF- $\alpha$ via an increase in the adiponectin concentration in order to induce beneficial effects. Further, many reports indicate that these TZDs actually increase LDL cholesterol levels. Nevertheless, adiponectin has been shown to inhibit atherosclerosis in vitro and in vivo, suggesting that it might prevent the onset and progression of CVDs in diabetic patients and also in patients with metabolic syndrome.

\section{Effects of genetic factors on serum adiponectin concentration}

A genetic study of French caucasions revealed that the long arm of chromosome 3 (3q27), which harbors the adiponectin gene, is strongly involved in type 2 diabetes mellitus ${ }^{56}$. Furthermore, a linkage analysis in white families indicated that the $3 \mathrm{q} 27$ region is strongly associated with metabolic syndrome ${ }^{57)}$.

Hara et al. studied the single nucleotide polymorphisms (SNPs) of the adiponectin gene ${ }^{58)}$ and reported that the GG genotype of SNP45 and the GG genotype of SNP276 were frequently observed in diabetic patients. In particular, obese subjects with the GG genotype of SNP276 had a lower serum adiponectin concentration and higher HOMA-IR. Kondo et al. reported that a change of the 164th amino acid of adiponectin from isoleucine to threonine (Thr), which is quite a rare mutation, was related to a lower adiponectin concentration, and that all 9 subjects with the Thr-allele had at least one symptom of metabolic syndrome as a complication, such as diabetes mellitus, hypertension, dyslipidemia, and CVDs ${ }^{59)}$.

We also investigated SNP45, SNP276, and SNP349 in the adiponectin gene and the SNP whose 12th amino acid (proline) in the PPARy gene was substituted with alanine (Ala) by using the TaqMan PCR method ${ }^{32)}$. There was no difference in the serum HMW adiponectin concentration between the 3 SNPs of the adiponectin gene in our healthy population. On the other hand, the serum HMW adiponectin concentration was significantly lower in patients with the Ala-allele of the PPAR $y$ gene in both males and females, which suggested that the concentration depends on genetic factors ${ }^{32)}$. With regard to the mecha- 


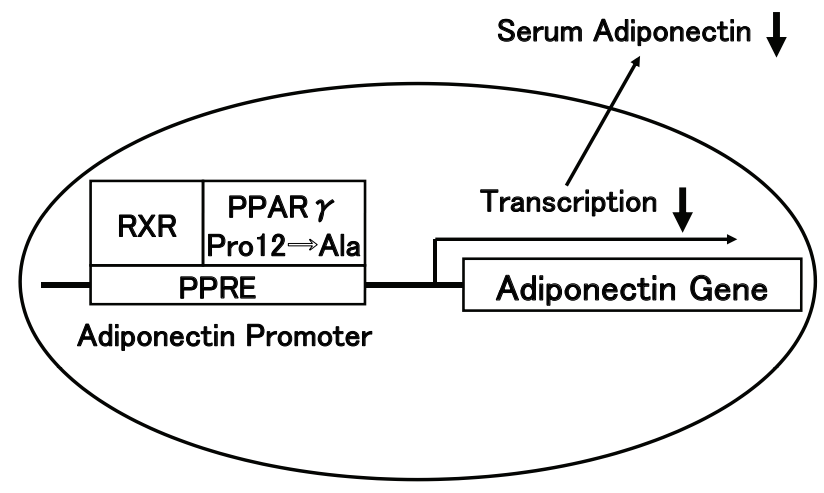

Fig. 4. Possible mechanism by which the subjects with the Ala12 allele in the PPAR $y$ gene have lower adiponectin promoter activity, resulting in a lower adiponectin level in circulation.

nism, experiments in vitro have revealed that human PPAR $y 2$ with Ala12 has reduced transactivation activity ${ }^{60)}$ and that the promoter activity of adiponectin is markedly enhanced by PPAR $y$ ligands in 3T3L1 adipocytes. Taking these findings into account, it is possible that subjects with the Ala12 allele have lower adiponectin promoter activity, resulting in a lower serum adiponectin level (Fig.4). These findings suggest that the serum adiponectin level is decreased due to obesity and genetic predispositions and is involved in glucose and/or lipid metabolism.

\section{CONCLUSION}

Previous studies in vitro and in vivo have indicated that adiponectin inhibits atherosclerosis, suggesting that adiponectin might prevent the onset and progression of cardiovascular diseases in patients with metabolic syndrome and in diabetic patients. It is suggested that HMW adiponectin is a useful marker for the evaluation and care of subjects with metabolic syndrome and related disorders.

\section{Acknowledgments}

The studies described here were conducted according to the principles expressed in the Declaration of Helsinki. Informed consent was obtained from each subject or patient after a full explanation of the purpose, nature, and risk of all procedures used. The protocols were approved by the ethical review committees of the Health Center and the Department of Internal Medicine, School of Medicine, Keio University, Tokyo, Japan.

These studies were supported in part by a Grantin-Aid from the Ministry of Education, Culture,
Sports, Science and Technology, Japan, and by research grants to H.H. including Nateglinide Memorial Toyoshima Research and Education Fund from Keio University, Tokyo. Fujirebio Inc. and Keio University have a patent for HMW adiponectin measurement.

\section{References}

1) Matsuzawa $Y$, Funahashi T, and Nakamura T: Molecular mechanism of metabolic syndrome X: contribution of adipocytokines adipocyte-derived bioactive substances. Ann NY Acad Sci, 1999; 892: 146-154

2) Reaven GM: Banting lecture 1988. Role of insulin resistance in human disease. Diabetes, 1988; 37: 1595-1607

3) Kaplan NM: The deadly quartet. Upper-body obesity, glucose intolerance, hypertriglyceridemia, and hypertension. Arch Intern Med, 1989; 149: 1514-1520

4) DeFronzo RA and Ferrannini E: Insulin resistance. A multifaceted syndrome responsible for NIDDM, obesity, hypertension, dyslipidemia, and atherosclerotic cardiovascular disease. Diabetes Care, 1991; 14: 173-194

5) Nakamura T, Tsubono Y, Kameda-Takemura K, Funahashi T, Yamashita S, Hisamichi S, Kita T, Yamamura T, and Matsuzawa Y: Magnitude of sustained multiple risk factors for ischemic heart disease in Japanese employees: a case-control study. Jpn Circ J, 2001; 65: 11-17

6) Maeda K, Okubo K, Shimomura I, Funahashi T, Matsuzawa $\mathrm{Y}$, and Matsubara K: cDNA cloning and expression of a novel adipose specific collagen-like factor, apM1 (AdiPose Most abundant Gene transcript 1). Biochem Biophys Res Commun, 1996; 221: 286-289

7) Nakano Y, Tobe T, Choi MN, Mazda T, and Tomita M: Isolation and characterization of GBP28, a novel gelatinbinding protein purified from human plasma. J Biochem (Tokyo), 1996; 120: 803-812

8) Yamauchi T, Kamon J, Waki H, Terauchi Y, Kubota N, Hara K, Mori Y, Ide T, Murakami K, Tsuboyama-Kasaoka N, Ezaki O, Akanuma Y, Gavrilova O, Vinson C, Reitman ML, Kagechika H, Shudo K, Yoda M, Nakano Y, Tobe K, Nagai R, Kimura S, Tomita M, Froguel P, and Kadowaki T: The fat-derived hormone adiponectin reverses insulin resistance associated with both lipoatrophy and obesity. Nat Med, 2001; 7: 941-946

9) Berg AH, Combs TP, Du X, Brownlee M, and Scherer PE: The adipocyte-secreted protein Acrp30 enhances hepatic insulin action. Nat Med, 2001; 7: 947-953

10) Hotta K, Funahashi T, Bodkin NL, Ortmeyer HK, Arita Y, Hansen BC, and Matsuzawa Y: Circulating concentrations of the adipocyte protein adiponectin are decreased in parallel with reduced insulin sensitivity during the progression to type 2 diabetes in rhesus monkeys. Diabetes, 2001; 50: 1126-1133

11) Kubota N, Terauchi Y, Yamauchi T, Kubota T, Moroi M, Matsui J, Eto K, Yamashita T, Kamon J, Satoh H, Yano W, Froguel P, Nagai R, Kimura S, Kadowaki T, and Noda T: Disruption of adiponectin causes insulin resistance and neointimal formation. J Biol Chem, 2002; 277: 2586325866 
12) Maeda N, Shimomura I, Kishida K, Nishizawa H, Matsuda M, Nagaretani H, Furuyama N, Kondo H, Takahashi M, Arita Y, Komuro R, Ouchi N, Kihara S, Tochino Y, Okutomi K, Horie M, Takeda S, Aoyama T, Funahashi T, and Matsuzawa Y: Diet-induced insulin resistance in mice lacking adiponectin/ACRP30. Nat Med, 2002; 8: 731-737

13) Kamada Y, Tamura S, Kiso S, Matsumoto H, Saji Y, Yoshida Y, Fukui K, Maeda N, Nishizawa H, Nagaretani $H$, Okamoto Y, Kihara S, Miyagawa J, Shinomura Y, Funahashi T, and Matsuzawa Y: Enhanced carbon tetrachloride-induced liver fibrosis in mice lacking adiponectin. Gastroenterology, 2003; 125: 1796-1807

14) Bråkenhielm E, Veitonmäki N, Cao R, Kihara S, Matsuzawa Y, Zhivotovsky B, Funahashi T, and Cao Y: Adiponectin-induced antiangiogenesis and antitumor activity involve caspase-mediated endothelial cell apoptosis. Proc Natl Acad Sci USA, 2004; 101: 2476-2481

15) Otabe S, Yuan X, Fukutani T, Wada N, Hashinaga T, Nakayama H, Hirota N, Kojima M, and Yamada K: Overexpression of human adiponectin in transgenic mice results in suppression of fat accumulation and prevention of premature death by high-calorie diet. Am J Physiol Endocrinol Metab, 2007; 293: E210-E218

16) Kobayashi H, Ouchi N, Kihara S, Walsh K, Kumada M, Abe Y, Funahashi T, and Matsuzawa Y: Selective suppression of endothelial cell apoptosis by the high molecular weight form of adiponectin. Circ Res, 2004; 94: e27-e31

17) Pajvani UB, Hawkins M, Combs TP, Rajala MW, Doebber T, Berger JP, Wagner JA, Wu M, Knopps A, Xiang AH, Utzschneider KM, Kahn SE, Olefsky JM, Buchanan TA, and Scherer PE: Complex distribution, not absolute amount of adiponectin, correlates with thiazolidinedionemediated improvement in insulin sensitivity. J Biol Chem, 2004; 279: 12152-12162

18) Ouchi N, Kobayashi H, Kihara S, Kumada M, Sato K, Inoue T, Funahashi T, and Walsh K: Adiponectin stimulates angiogenesis by promoting cross-talk between AMPactivated protein kinase and Akt signaling in endothelial cells. J Biol Chem, 2004; 279: 1304-1309

19) Wang Y, Lam KS, Xu JY, Lu G, Xu LY, Cooper GJ, and $\mathrm{Xu}$ A: Adiponectin inhibits cell proliferation by interacting with several growth factors in an oligomerization-dependent manner. J Biol Chem, 2005; 280: 18341-18347

20) Aso Y, Yamamoto R, Wakabayashi S, Uchida T, Takayanagi $\mathrm{K}$, Takebayashi $\mathrm{K}$, Okuno $\mathrm{T}$, Inoue $\mathrm{T}$, Node $\mathrm{K}$, Tobe $\mathrm{T}$, Inukai $\mathrm{T}$, and Nakano Y: Comparison of serum highmolecular-weight (HMW) adiponectin with total adiponectin concentrations in type 2 diabetic patients with coronary artery disease using a novel enzyme-linked immunosorbent assay to detect HMW adiponectin. Diabetes, 2006; 55: 1954-1960

21) Waki H, Yamauchi T, Kamon J, Ito Y, Uchida S, Kita S, Hara K, Hada Y, Vasseur F, Froguel P, Kimura S, Nagai R, and Kadowaki T: Impaired multimerization of human adiponectin mutants associated with diabetes: Molecular structure and multimer formation of adiponectin. J Biol Chem, 2003; 278: 40352-40363

22) Hara K, Horikoshi M, Yamauchi T, Yago H, Miyazaki O, Ebinuma H, Imai Y, Nagai R, and Kadowaki T: Measurement of the high-molecular weight form of adiponectin in plasma is useful for the prediction of insulin resistance and metabolic syndrome. Diabetes Care, 2006; 29: 1357-1362

23) Seino Y, Hirose H, Saito I, and Itoh H: High molecular weight multimer form of adiponectin as a useful marker to evaluate insulin resistance and metabolic syndrome in Japanese men. Metabolism, 2007; 56: 1493-1499

24) Nakashima R, Kamei N, Yamane K, Nakanishi S, Nakashima A, and Kohno N: Decreased total and high molecular weight adiponectin are independent risk factors for the development of type 2 diabetes in Japanese-Americans. J Clin Endocrinol Metab, 2006; 91: 3873-3877

25) Inoue T, Kotooka N, Morooka T, Komoda H, Uchida T, Aso Y, Inukai T, Okuno T, and Node K: High molecular weight adiponectin as a predictor of long-term clinical outcome in patients with coronary artery disease. Am J Cardiol, 2007; 100: 569-574

26) Arita Y, Kihara S, Ouchi N, Takahashi M, Maeda K, Miyagawa J, Hotta K, Shimomura I, Nakamura T, Miyaoka K, Kuriyama H, Nishida M, Yamashita S, Okubo K, Matsubara K, Muraguchi M, Ohmoto Y, Funahashi T, and Matsuzawa Y: Paradoxical decrease of an adipose-specific protein, adiponectin, in obesity. Biochem Biophys Res Commun, 1999; 257: 79-83

27) Hotta K, Funahashi T, Arita Y, Takahashi M, Matsuda M, Okamoto Y, Iwahashi H, Kuriyama H, Ouchi N, Maeda K, Nishida M, Kihara S, Sakai N, Nakajima T, Hasegawa K, Muraguchi M, Ohmoto Y, Nakamura T, Yamashita S, Hanafusa T, and Matsuzawa Y: Plasma concentrations of a novel, adipose-specific protein, adiponectin, in type 2 diabetic patients. Arterioscler Thromb Vasc Biol, 2000; 20: 1595-1599

28) Weyer C, Funahashi T, Tanaka S, Hotta K, Matsuzawa Y, Pratley RE, and Tataranni PA: Hypoadiponectinemia in obesity and type 2 diabetes: close association with insulin resistance and hyperinsulinemia. J Clin Endocrinol Metab, 2001; 86: 1930-1935

29) Yamamoto $Y$, Hirose H, Saito I, Tomita M, Taniyama M, Matsubara K, Okazaki Y, Ishii T, Nishikai K, and Saruta T: Correlation of adipocyte-derived protein, adiponectin with insulin resistance index and serum HDL-cholesterol, independent of body mass index in the Japanese population. Clin Sci, 2002; 103: 137-142

30) Hirose H, Kawai T, Yamamoto Y, Taniyama M, Tomita M, Matsubara K, Okazaki Y, Ishii T, Oguma Y, Takei I, and Saruta T: Effects of pioglitazone on metabolic parameters, body fat distribution, and serum adiponectin levels in Japanese male patients with type 2 diabetes. Metabolism, 2002; 51: 314-317

31) Yamamoto Y, Hirose H, Saito I, Nishikai K, and Saruta T: Adiponectin, an adipocyte-derived protein, predicts future insulin resistance: two-year follow-up study in Japanese population. J Clin Endocrinol Metab, 2004: 89: 87-90

32) Yamamoto Y, Hirose H, Miyashita K, Nishikai K, Saito I, Taniyama M, Tomita M, and Saruta T: PPAR 2 gene Pro12Ala polymorphism may influence serum level of an adipocyte-derived protein, adiponectin, in the Japanese population. Metabolism, 2002; 51: 1407-1409

33) Nakano Y, Tajima S, Yoshimi A, Akiyama H, Tsushima M, Tanioka T, Negoro T, Tomita M, and Tobe T: A novel en- 
zyme-linked immunosorbent assay specific for high-molecular-weight adiponectin. J Lipid Res, 2006; 47: 15721582

34) Daimon M, Oizumi T, Saitoh T, Kameda W, Hirata A, Yamaguchi $\mathrm{H}$, Ohnuma $\mathrm{H}$, Igarashi $M$, Tominaga $M$, and Kato T: Decreased serum levels of adiponectin are a risk factor for the progression to type 2 diabetes in the Japanese population: the Funagata study. Diabetes Care, 2003; 26: 2015-2020

35) Pischon T, Girman CJ, Hotamisligil GS, Rifai N, Hu FB, and Rimm EB: Plasma adiponectin levels and risk of myocardial infarction in men. JAMA, 2004; 291: 17301737

36) Seino Y, Hirose H, Saito I, and Itoh H: High molecular weight adiponectin is a predictor of progression to metabolic syndrome: a population-based 6-year follow-up study in Japanese men. Metabolism, 2009; 58: 355-360

37) Kappert K, Tsuprykov O, Kaufmann J, Fritzsche J, Ott I, Goebel M, Bähr IN, Hässle PL, Gust R, Fleck E, Unger T, Stawowy P, and Kintscher U: Chronic treatment with losartan results in sufficient serum levels of the metabolite EXP3179 for PPARgamma activation. Hypertension, 2009; 54: 738-743

38) Uchida T, Shimizu M, Sakai Y, Nakano T, Hara K, Takebayashi K, Inoue T, Node K, Inukai T, Takayanagi K, and Aso Y: Effects of losartan on serum total and high-molecular weight adiponectin concentrations in hypertensive patients with metabolic syndrome. Metabolism, 2008; 57: 1278-1285

39) Nishimura H, Sanaka T, Tanihata $Y$, Naito T, Higuchi C, and Otsuka K: Losartan elevates the serum high-molecular weight-adiponectin isoform and concurrently improves insulin sensitivity in patients with impaired glucose metabolism. Hypertens Res, 2008; 31: 1611-1618

40) Watanabe S, Okura T, Kurata M, Irita J, Manabe S, Miyoshi K, Fukuoka T, Murakami K, and Higaki J: The effect of losartan and amlodipine on serum adiponectin in Japanese adults with essential hypertension. Clin Ther, 2006; 28: 1677-1685

41) Aksnes TA, Seljeflot I, Torjesen PA, Höieggen A, Moan A, and Kjeldsen SE: Improved insulin sensitivity by the angiotensin II-receptor blocker losartan is not explained by adipokines, inflammatory markers, or whole blood viscosity. Metabolism, 2007; 56: 1470-1477

42) Guo LL, Pan Y, and Jin HM: Adiponectin is positively associated with insulin resistance in subjects with type 2 diabetic nephropathy and effects of angiotensin II type 1 receptor blocker losartan. Nephrol Dial Transplant, 2009; 24: $1876-1883$

43) Piecha G, Adamczak M, Chudek J, and Wiecek A: Indapamide decreases plasma adiponectin concentration in patients with essential hypertension. Kidney Blood Press Res, 2007; 30: 187-194

44) Zappe DH, Sowers JR, Hsueh WA, Haffner SM, Deedwania PC, Fonseca VA, Keeling L, and Sica DA: Metabolic and antihypertensive effects of combined angiotensin receptor blocker and diuretic therapy in prediabetic hypertensive patients with the cardiometabolic syndrome. J Clin Hypertens, 2008; 10: 894-903

45) Huang SS, Wu TC, Lin SJ, and Chen JW: Combination of an ACE inhibitor and indapamide improves blood pressure control, but attenuates the beneficial effects of ACE inhibition on plasma adiponectin in patients with essential hypertension. Circ J, 2009; 73: 2282-2287

46) Hirose H, Kawabe H, and Saito I: Effects of losartan/ hydrochlorothiazide treatment, after change from ARB at usual dosage, on blood pressure and various metabolic parameters including high-molecular weight adiponectin in Japanese male hypertensive subjects. Clin Exp Hypertens, 2010; in press

47) Schupp M, Janke J, Clasen R, Unger T, and Kintscher U: Angiotensin type 1 receptor blockers induce peroxisome proliferator-activated receptor-gamma activity. Circulation, 2004; 109: 2054-2057

48) Clasen R, Schupp M, Foryst-Ludwig A, Sprang C, Clemenz $M$, Krikov $M$, Thöne-Reineke $C$, Unger $T$, and Kintscher U: PPARgamma-activating angiotensin type-1 receptor blockers induce adiponectin. Hypertension, 2005; 46: 137-143

49) Yamagishi $S$ and Takeuchi M: Telmisartan is a promising cardiometabolic sartan due to its unique PPAR-gammainducing property. Med Hypotheses, 2005; 64: 476-478

50) Nakaya K, Ayaori M, Hisada T, Sawada S, Tanaka N, Iwamoto N, Ogura M, Yakushiji E, Kusuhara M, Nakamura $\mathrm{H}$, and Ohsuzu F: Telmisartan enhances cholesterol efflux from THP-1 macrophages by activating PPARgamma. J Atheroscler Thromb, 2007; 14: 133-141

51) Komiya N, Hirose H, Kawabe H, Itoh H, and Saito I: Effects of telmisartan therapy on metabolic profiles and serum high molecular weight (HMW)-adiponectin level in Japanese male hypertensive subjects with abdominal obesity. J Atheroscler Thromb, 2009; 16: 137-142

52) Kawai T, Takei I, Oguma Y, Ohashi N, Tokui M, Oguchi S, Katsukawa F, Hirose H, Shimada A, Watanabe K, and Saruta $\mathrm{T}$ : Effects of troglitazone on fat distribution in the treatment of male type 2 diabetes. Metabolism, 1999; 48: 1102-1107

53) Dormandy JA, Charbonnel B, Eckland DJ, Erdmann E, Massi-Benedetti M, Moules IK, Skene AM, Tan MH, Lefebvre PJ, Murray GD, Standl E, Wilcox RG, Wilhelmsen L, Betteridge J, Birkeland K, Golay A, Heine RJ, Korányi L, Laakso M, Mokán M, Norkus A, Pirags V, Podar T, Scheen A, Scherbaum W, Schernthaner G, Schmitz O, Skrha J, Smith U, and Taton J; PROactive investigators: Secondary prevention of macrovascular events in patients with type 2 diabetes in the PROactive Study (PROspective pioglitAzone Clinical Trial In macroVascular Events): a randomised controlled trial. Lancet, 2005; 366: 1279-1289

54) Maeda N, Takahashi M, Funahashi T, Kihara S, Nishizawa H, Kishida K, Nagaretani H, Matsuda M, Komuro R, Ouchi N, Kuriyama H, Hotta K, Nakamura T, Shimomura I, and Matsuzawa Y: PPAR $y$ ligands increase expression and plasma concentrations of adiponectin, an adipose-derived protein. Diabetes, 2001; 50: 2094-2099

55) Yang WS, Jeng CY, Wu TJ, Tanaka S, Funahashi T, Matsuzawa Y, Wang JP, Chen CL, Tai TY, and Chuang LM: Synthetic peroxisome proliferator-activated receptor-gamma agonist, rosiglitazone, increases plasma levels of adiponectin in type 2 diabetic patients. Diabetes Care, 2002; 25: $376-380$ 
56) Vionnet N, Hani El H, Dupont $S$, Gallina $S$, Francke $S$, Dotte S, De Matos F, Durand E, Leprêtre F, Lecoeur C, Gallina P, Zekiri L, Dina C, and Froguel P: Genomewide search for type 2 diabetes-susceptibility genes in French whites: evidence for a novel susceptibility locus for earlyonset diabetes on chromosome 3q27-qter and independent replication of a type 2-diabetes locus on chromosome 1q21-q24. Am J Hum Genet, 2000; 67: 1470-1480

57) Kissebah AH, Sonnenberg GE, Myklebust J, Goldstein M, Broman K, James RG, Marks JA, Krakower GR, Jacob HJ, Weber J, Martin L, Blangero J, and Comuzzie AG: Quantitative trait loci on chromosomes 3 and 17 influence phenotypes of the metabolic syndrome. Proc Natl Acad Sci USA, 2000; 97: 14478-14483

58) Hara K, Boutin P, Mori Y, Tobe K, Dina C, Yasuda K, Yamauchi T, Otabe S, Okada T, Eto K, Kadowaki H, Hagura R, Akanuma Y, Yazaki Y, Nagai R, Taniyama M,
Matsubara K, Yoda M, Nakano Y, Tomita M, Kimura S, Ito C, Froguel P, and Kadowaki T: Genetic variation in the gene encoding adiponectin is associated with an increased risk of type 2 diabetes in the Japanese population. Diabetes, 2002; 51: 536-540

59) Kondo H, Shimomura I, Matsukawa Y, Kumada M, Takahashi M, Matsuda M, Ouchi N, Kihara S, Kawamoto T, Sumitsuji S, Funahashi T, and Matsuzawa Y: Association of adiponectin mutation with type 2 diabetes: a candidate gene for the insulin resistance syndrome. Diabetes, 2002; 51: 2325-2328

60) Deeb SS, Fajas L, Nemoto M, Pihlajamäki J, Mykkänen L, Kuusisto J, Laakso M, Fujimoto W, and Auwerx J: A Pro12Ala substitution in PPARgamma2 associated with decreased receptor activity, lower body mass index and improved insulin sensitivity. Nat Genet, 1998; 20: 284287 